\title{
FOSL2 Gene
}

National Cancer Institute

\section{Source}

National Cancer Institute. FOSL2 Gene. NCI Thesaurus. Code C18418.

This gene is involved in cellular proliferation and apoptosis. 